\title{
ON THE VALUE OF INDUSTRIAL SERVICE
}

\author{
Pontus Johansson \\ Department of Production Economics \\ Linköping Institute of Technology \\ SE-581 83 Linköping, Sweden \\ pontus.johansson@ipe.liu.se
}

This paper deals with the value of industrial services, i.e. the supply of after sales services to industrial users of capital goods. A tool is proposed that measure the monetary value of future industrial service activities, and that considers non-monetary values as well. The paper further highlights the need for an increased strategic focus on manufacturing firms' industrial service business.

\section{INTRODUCTION}

Kotler (1997, p. 52) defines a profitable customer as one “...that over time yields a revenue stream that exceeds by an acceptable amount the company's cost stream of attracting, selling, and servicing that customer". Profits are measured monetarily and presented through accounting statements, value on the other hand is a bit trickier; what is for example the value of a good customer relation?

Manufacturing firms are traditionally viewed upon as producing and selling goods and that through the transaction of goods for money the customer takes over the produced item. For strategic planning of manufacturing activities a strong theoretical foundation has been laid (see Skinner, 1969, Hayes and Wheelwright 1979a and 1979b, Hill, 2000). With manufacturers delivering an increasing amount of services, more and/or new strategic tools are required. Turning away from goods production and looking at "pure" services, they come in many variations and several attempts to categorize them has been made, see for example Schmenner (1986), Silvestro et al. (1992), Kellogg and Nie (1995), Lele (1997), Cohen et al. (2000), and Buzacott (2000). This paper deals with an intersection of goods and services which here is called Industrial Service, and defined as the supply of after sales services, such as spare parts, consumables, education, repair services, and upgrades, related to the maintenance of industrial goods.

The focus of this paper is the monetary value of supplying industrial service, and the purpose is to develop a decision tool which adjusts for interest rates, inflation, and uncertainty, to be used by after sales managers. Furthermore, a discussion is held on how to assess non-monetary customer value, which could be translated into revenue potential for the industrial service provider. 
Although the results are aimed at ultimately finding a use in industrial applications, this paper as it is should be seen as theory generating. Empirical testing and evaluation is still to be carried out, and could lead to corrections of the proposed decision tools. The theory used in this paper is taken from numerous research fields, including manufacturing strategy, service management, corporate finance, and marketing.

This paper first looks at after sales characteristics, especially in monetary terms and in a consideration of the outlook for this kind of business. The first part also discusses good/service aspects of various products. Secondly, a summary is made on the use and application of net present value (NPV). Next follows an analysis of the value of industrial services, focused on methods to measure monetary value. Then comes a section containing the conclusions to be drawn from the analysis, and finally there is a discussion on the managerial impact of the conclusions, including ideas for future research.

\section{AFTER SALES CHARACTERISTICS}

A building ground for the coming discussion is that a product can consist of a good, a service, or both. After sales service and thereby also industrial service, which is a subset of the former, is considered to be a product, thus capable of having both good and service characteristics. It is also of importance to note that after sales service goes by many names, according to Goffin and New (2001) these include customer support, product support, technical support, and service.

Knecht et al. (1993) consider the after sale market as a largely unexplored opportunity for industrial companies. Their investigations state that after sales business accounts for $10-20 \%$ of revenue in their four company types, but at the same time $20-40 \%$ of profit contribution. Wise and Baumgartner (1999) also point to after sale activities as one part of their conclusion that many manufacturing companies could profit by expanding down the value chain. Marsh (1999) point out that most engineering companies already have after sales divisions, and that these are increasingly becoming the focus of operations.

Looking at the customers who purchase the industrial service also reveal how large the business potential is. The major Swedish rail company, SJ, is a large customer of various after sales services. Comparing their expenses for vehicle maintenance (i.e., after sales service) to their expenses for acquiring new rolling stock exposes that the company spends roughly twice as much on vehicle maintenance as on new acquires (SJ, 2001).

Levitt, in the 1983 article "After the sale is over...", considered how products were, and would be, valued. He claimed that goods (items using Levitt's term) had gone from being just a simple product to being an augmented product, and in the future would transform to system contracts. He further said that service would increase in value from modest in the past to important in 1983 to vital in the future. It is difficult to argue against these claims, and today we are in what Levitt in 1983 called the future. So, what is next?

A very logical reasoning for the changing strategies in after sales service is made by Lele (1997). The alterations predicted by Lele are (i) Service contracts will become an endangered species, (ii) Support services will be unbundled, and (iii) 
Profits will be squeezed. Thus the conclusions to draw from Lele's paper is that manufacturers will find their profitability shrunk not only from new sales competition but also in the previously so successful after sales business, and to remain overall competitive companies must include after sales activities into their strategic planning. However, based on the possibilities to increase revenues from service activities - albeit at lower profitability - an increased importance of services in general and after sales services in particular is to be expected. (Wise and Baumgartner, 1999, Cohen et al., 2000, Mathieu, 2001).

In providing after sales services, the original equipment manufacturer (OEM) has numerous advantages. Among these are product knowledge, access to drawings, existing customer relations, and market knowledge. The possibilities for $3^{\text {rd }}$ party companies to compete with their own industrial service products must however be seen as increasing. Powerful computers and CNC-machinery make fast reengineering of goods a realistic option, and modern information technology greatly increases market access. This reasoning supports the conclusion that after sales competition will be tougher in the future.

\section{NET PRESENT VALUE}

There is a considerable difference between cash flow and the accounting income statement. For the purpose of finding a capital investment's value cash flows should be, and normally is, used (see for example Ross et al., 1996). To explain the difference, let us consider a firm buying a building for $€ 500,000$. The entire sum is an immediate cash flow (cost), but from an accounting perspective with a 50 years straight depreciation the cost, or earnings reduction, is only $€ 10,000$. There is however no doubt that the company needs to fully finance the cash outflow of $€$ 500,000 .

The net present value (NPV) of a project is found by considering all future cash flows stemming from the project at hand. Furthermore, only incremental cash flows are considered, that is, we look at the difference in the company's cash flow with or without the project.

Mathematically, there are two basic ways to determine an NPV, both giving correct answers (at least as correct as the input) but useful for different applications. Firstly, cash flows are considered as time-discrete events, which are discounted to a net present value in time zero as shown by:

$$
N P V=\sum_{i=0}^{N} a_{i}(1+r)^{-i}
$$

Formula (1)

where $a_{i}$ is the discrete cash flow (annuity) $a$ at time $i$, discounted with the interest rate $r$.

Secondly, cash flows can be considered as a continuous stream, giving that net present value is found through integration:

$$
N P V=\int_{0}^{T} a(\tau) e^{-\rho \tau} d \tau
$$

Formula (2) 
with $a(\tau)$ being the cash flow stream at time $\tau$ discounted with the continuous interest rate $\rho=\ln (l+r)$ when one year is used as the time base.

The use of NPV as a tool has become quite simple compared to earlier. Strong analytical skills that were once required to solve difficult sums and integrations have now been replaced (or at least greatly facilitated) by the now common use of computers and spreadsheet programs. For more details on the use of NPV, see Ross et al. (1996), or basically any other textbook on corporate finance/capital budgeting.

\section{THE VALUE OF INDUSTRIAL SERVICES}

In chapter 2 it was found that after sales services, and thus industrial services, are normally profitable. Here methods for finding the value, beyond accounting principles, of such products are investigated. The last subsection of this chapter contains a summary of the presented methods.

\subsection{Bottom Line}

In a steady state condition the ratio between new sales and after sales would remain constant. Both contribute with revenue and profits (or losses), and over time not much change is expected. To increase company value it is thus enough to focus on increasing this year's bottom line, for example by investigating the effect of changing margins, sales volume, market share, costs, price, etc., and efforts are concentrated on the area with would give the best yield.

The presumption made about no change over time is in "the real world" very unlikely. The practice of focusing on the present year's bottom line is however a viable method in attempts to maximize profits and increase shareholder value. When valuing a company, it is simple to use historical data; future cash flows are harder to estimate. Many analytical methods for valuing a company therefore put a strong emphasis on the latest financial reports, and thus motivate companies to focus on the bottom line.

It is easy to criticize a bottom line focus as being to shortsighted and possibly even destroying potential future value. But, since shareholder value is undeniably important to many companies, the bottom line effect of industrial service activities is one method to use.

\subsection{Single Project}

Company A has just signed a contract to supply company B with a new production facility. The price is 10000 monetary units (monetary unit = FMU), and due to tough competition in the bidding process, the profit for A is only FMU 200 (or 2\%). However, company A expects to provide industrial services the coming years, but this has not been included in the sales calculation. What is the present value of providing these services?

In calculating the value, future cash flows are discounted with respect to interest rates, inflation and uncertainty. If prices change in line with general inflation, a real interest rate is preferably used, if not it is often easier to use a nominal interest rate. The relation between the two is $\left(r_{n} / r_{r}=\right.$ nominal/real interest rate, $h=$ inflation): 


$$
1+r_{n}=\left(1+r_{r}\right) \times(1+h)
$$

Formulae (3)

Assuming that real prices are viable, the forecasted real cash flow of the industrial service supply is shown with striped columns in Figure 1. Only the net cash flow is presented, calculated as $20 \%$ profit on an order size that annually is $5 \%$ of the initial order. Year 1 is covered by warranties, and in year 9 a major retrofit is sold, increasing the final years' cash flow as well. The gray columns show the discounted value of each year's cash flow, which is summarized into an NPV. Tax is assumed to be $30 \%$.

The calculation is done using formulae (1) with an interest rate of $25 \%$. The discount interest rate is derived from a company cost of capital of $12,5 \%$ (interest rate required on investments) and adjusted for risk up to $25 \%$. In the end this calculation increases the value of the contract with FMU 325, to be added to the initial FMU 325.

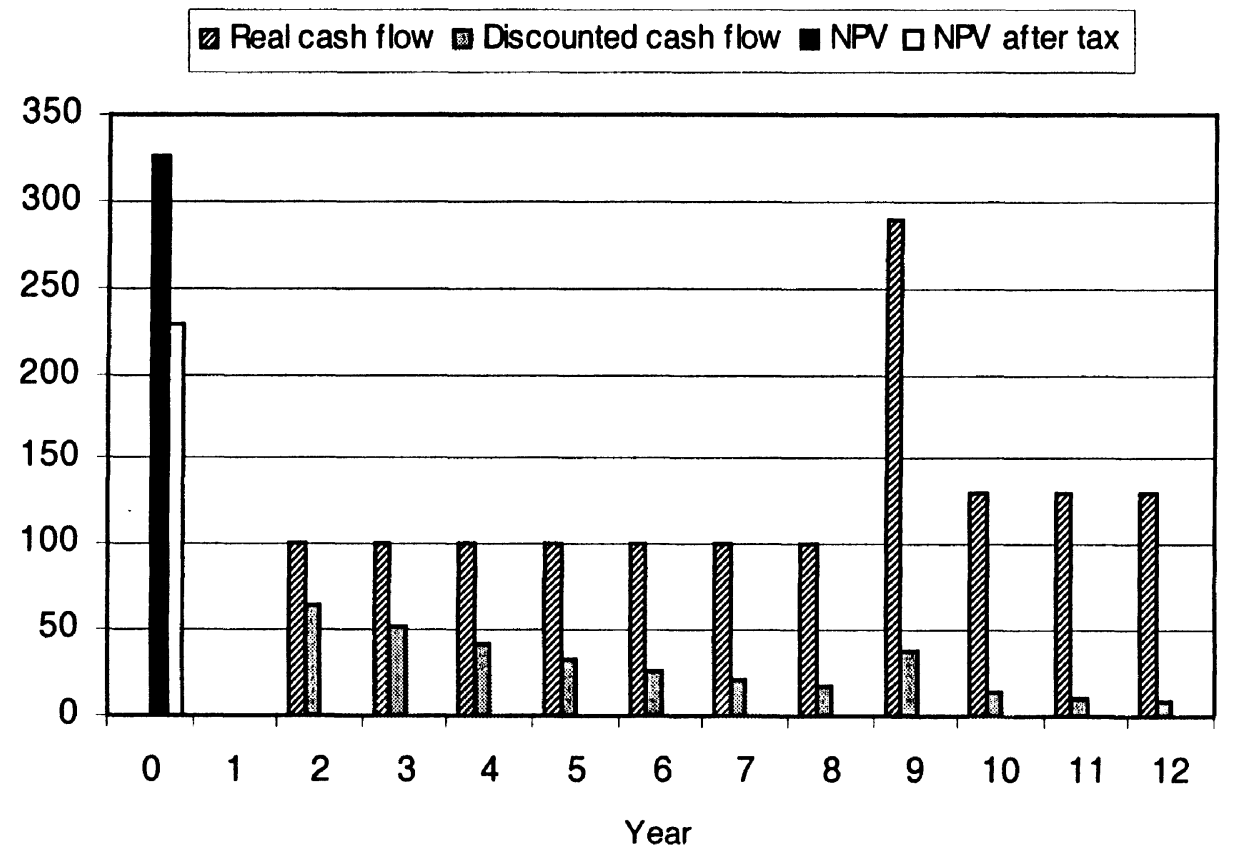

Figure 1 - Net present Value of a Forecasted Industrial Service Supply

\subsection{High Volume}

When valuating the life cycle cost/profit/income of industrial service, the continuous NPV calculation has some strong sides. A basic requirement however is that future cash flows can be described as a function of time.

Armistead and Clark (1991) shed some light on how a product's life cycle affect after sales activities. The authors suggest strategies for dealing with the various stages of the life cycle, but without measuring the value. If the life cycle can be described mathematically, formula (2) is quite easily used to discount, with adjustment for risk, inflation, and interest rates, the life cycle into a NPV.

When performing an NPV as described here, it is important to consider where in the life cycle the calculation is made. Any economic activity, whether resulting in 
positive or negative cash flow, that has already taken place is not included in the NPV, but is considered a "sunk costs". Only future cash flows shall be included.

\subsection{Non-Monetary}

Cohen et al. (2000) use Saturn Corporation as a case example on how to build the link between after sales service and customer loyalty. This link is considered to be critical, and the authors claim that a supply-chain strategy targeted at service is one key to achieve customer satisfaction. Taking into account the potential value from returning customers, careful management of the service supply-chain is one way to find value through industrial service.

Outsourcing, core competence, and other management theories changes the way maintenance activities are carried out at the industrial service customers (Sherwin, 2001). Sherwin criticizes how maintenance is commonly measured "against artificial targets fixed according to MBO [management by objectives] principles" (p. 163), and instead advocates contributions to life cycle profit as superior to shortsighted "bottom line" management. Thus it should be the industrial service supplier's task to deliver such life cycle profit in what could hopefully be a win-win situation.

Industrial service can also be considered as an I/O condition for a manufacturing company. Using the concepts of order winner and order qualifier (Hill, 2000), being able to provide the right industrial service can be what wins (or qualifies) a company orders in the market.

\subsection{Choosing a Valuation Method}

Sections $4.1-4.4$ propose four different methods to think about the value of industrial service. The names given to these four methods say some about when they are applicable, but for clarification and easy overview Table 1 lists the pros and cons of each method.

Table 1 - How to Value Industrial Service

\begin{tabular}{|l|l|l|}
\hline Method & Pros & Cons \\
\hline Bottom line & $\begin{array}{l}\text { - Increase stock value } \\
\text { - Profit maximization }\end{array}$ & $\begin{array}{l}- \text { Effect on long term value } \\
\text { creation }\end{array}$ \\
\hline Single project & $\begin{array}{l}\text { - Intuitive, ease of use } \\
- \text { Considers interest rate, } \\
\text { inflation and uncertainty }\end{array}$ & $\begin{array}{l}- \text { False reliability through } \\
\text { "exact" numbers }\end{array}$ \\
\hline High volume & $\begin{array}{l}- \text { Analytical solution } \\
- \text { Considers interest rate, } \\
\text { inflation and uncertainty }\end{array}$ & $\begin{array}{l}- \text { Non-intuitive } \\
- \text { Only practical for simple } \\
\text { flows }\end{array}$ \\
\hline Non-monetary & $\begin{array}{l}- \text { Considers uncertainty to a } \\
\text { chosen extent } \\
- \text { For strategic planning }\end{array}$ & $\begin{array}{l}\text { - Hard to measure profit } \\
\text { contribution }\end{array}$ \\
\hline
\end{tabular}

\section{CONCLUSIONS}

This paper shows how traditional methods from financial theory can be applied to estimate the present value of future industrial service activities. It is further shown that depending on the conditions different methods are better suited than others. 
When considering all of the methods suggested here, they form a tool that can evaluate the importance of industrial service activities in a company.

One conclusion, which has been drawn by others as well, is that the increased merger of goods and services offers revenue and profit opportunities for manufacturing companies able to expand downstream by supplying industrial services. The tools provided in this paper can be used to highlight the strategic value of increasing a company's focus on this industrial service product.

Apart from the purely monetary valuation, the analysis also covers "softer" values of industrial services. When industrial service becomes a requirement to get orders at all, it is no longer a question of adding value, but of survival. This stresses the need for strategic thinking on manufacturing firms' after sales activities. Or, maybe better put:

"Rarely is customer service discretionary. It is a requisite of getting and holding business, just like the generic product itself." (Levitt, 1972, p. 10)

\section{MANAGERIAL IMPLICATIONS}

Increased competition (as discussed in section 2) means that an increased focus on industrial service is required to maintain or improve competitiveness. This paper hopefully highlights this problem (or opportunity, if thought of more positively). Apart from NPV calculations, decision theory is very likely a tool that could find use in strategic thinking regarding industrial service. In future work on industrial service such a tool ought to be investigated. Empirical testing of the proposed tool is another "next step".

Owning a tangible good is, in these days of core competency and outsourcing strategies, not central to many manufacturers. It is therefore likely that that the blending of new sales and after sales into functional sales is a phenomenon on the rising. At least it is a phenomenon worth to consider by managers of B2B manufacturers. The tool described in this paper should find use in most companies who are considering functional sales approaches. When ownership of a good is not transferred to the user, the future cash flows around the good become critical to measure.

What the supplier calls industrial service is often called maintenance by the customer. In an overview if maintenance management models by Sherwin (2001), one of the conclusions is that the use of modern IT should make it possible to manage maintenance activities in way that net contribution to life-cycle profit is maximized. An after sales manager that understands how to contribute to his/her customer's maintenance needs is in the right position to create value for both parties.

Your company provides a product, and to do that that a certain cost arises. For the costumer this product has a certain value, which should be higher than the production cost. This gap is divided between seller and buyer. In a competitive market there should be more than one supplier, and given two suppliers delivering products with identical value, the company with the lower cost will be the most profitable one. Thus the tendency among manufacturing companies to lower costs, and the opportunity to gain profits by increasing the created value is often overlooked. 
Risk adjustments in NPV calculation is likely based on gut feeling, requiring experienced managers for good results. The same can be said about forecasting industrial service cash flows, and as is valid for all calculations; output will not be more accurate than input.

\section{REFERENCES}

1. Armistead C, Clark G. A framework for formulating after-sales support strategy. International Journal of Operations \& Production Management 1991; 11(3): 111-124.

2. Buzacott, John A. Service system structure. International Journal of Production Economics 2000; 68(1): 15-27.

3. Cohen MA, Cull C, Lee HL, Willen D. Saturn's supply-chain innovation: high value in after-sales service. Sloan Management Review 2000; 41(4): 93-101.

4. Goffin K, New C. Customer support and new product development. International Journal of Operations \& Production Management 2001; 21(3): 275-301.

5. Hayes RH, Wheelwright SC. Link manufacturing processes and product life cycles. Harvard Business Review 1979a; January-February: 133-140.

6. Hayes RH, Wheelwright SC. The dynamics of process-product life cycles. Harvard Business Review 1979b; March-April: 127-136.

7. Hill, Terry. Manufacturing Strategy - Text and Cases, $2^{\text {nd }}$ edition. Houndsmills, Hampshire: Palgrave, 2000.

8. Kellogg DL, Nie W. A framework for strategic service management. Journal of Operations Management 1995; 13(4); 323-337.

9. Knecht T, Leszinski R, Webe FA. Making profits after the sale. The McKinsey Quarterly 1993; 4: 79 86.

10. Kotler, P. Marketing management - analysis, planning, implementation, and control, $9^{\text {th }}$ edition. Upper Saddle River, New Jersey: Prentice-Hall, 1997.

11. Lele, MM. After-sales service - necessary evil or strategic opportunity?. Managing Service Quality 1997; 7(3): 141-145.

12. Levitt, T. Production-line approach to service. Harvard Business Review 1972; September-October: Reprint 72505.

13. Levitt, T. After the sale is over... . Harvard Business Review 1983; September-October: Reprint 83511.

14. Marsh, P. At your service. Financial Times 1999; May 12.

15. Mathieu, V. Service strategies within the manufacturing sector: benefits, costs and partnership. International Journal of Service Industry Management 2001; 12(5): 451-475.

16. Ross SA, Westerfield RW, Jaffe J. Corporate finance, $4^{\text {th }}$ edition, International student edition. Irwin, 1996.

17. Schmenner, RW. How can service business survive and prosper?. Sloan Management Review 1986; 27(3): 21-32.

18. Sherwin, D. A review of overall models for maintenance management. Journal of Quality in Maintenance Engineering 2000; 6(3): 138-164.

19. Silvestro R, Fitzgerald L, Johnston R, Voss C. Towards a classification of service processes. International Journal of Service Industry Management 1992; 3(3): 62-75.

20. SJ. SJ Årsredovisning 2000. 2001. (Swedish railways, Annual report 2000).

21. Skinner, W. Manufacturing - missing link in corporate strategy. Harvard Business Review 1969; May-June: 136-145.

22. Wise R, Baumgartner P. Go downstream - the new profit imperative in manufacturing. Harvard Business Review 1999; September-October: 133-141. 